\title{
The Use of Arctic Science: POPs, the Stockholm Convention and Norway
}

\author{
Svein Vigeland Rottem ${ }^{\star}$ \\ Senior Research Fellow, Fridtjof Nansen Institute, Lysaker, Norway
}

\begin{abstract}
The focus in this article is on how scientific knowledge on POPs in the Arctic has been used in international regulations, and can be used today. More specifically, I explore Norway's active (and successful) nominations over the past decade of new POPs to the Stockholm Convention, nominations that need a scientific knowledge basis, and where Arctic scientific knowledge has been a prerequisite for action. The article will first discuss the Stockholm Convention's relation to other legal instruments on regulating POPs, and provide an introduction to how the Convention works. However, to obtain a more complete picture of how science travels into global governance we need to bring the State in. We need to know how scientific knowledge is used (or not used) at the national level. The question guiding the second part of this study is what has determined the use of scientific knowledge in Norwegian efforts leading to the nomination of new POPs to the Stockholm Convention. The focus is on environmental management design, state of knowledge, degree of political and economic controversy in the issue area, and the importance of the matter in public opinion and among policy makers. The conclusion is that Norway has had little to lose by initiating work on regulating new POPs and being active in the nomination of new POPs. Being green (or using scientific knowledge) in this case has been scientifically demanding, but politically easy.
\end{abstract}

Keywords: Arctic; POPs; Norway; Stockholm Convention; science

Responsible Editor: Øyvind Ravna.

Received: April 2017; Accepted: November 2017; Published: December 2017

\section{Introduction}

Climatic change and environmental challenges in the Arctic have been high on the international research agenda for some years. Wide-ranging studies on Arctic $^{1}$ climate change and painstaking research on pollutants have informed numerous attempts by the international community to regulate emissions. There are also studies that say something about whether and how this scientific knowledge has affected international environmental and climate policy. ${ }^{2}$ The evidence indicates that this repository of "Arctic knowledge"

^Correspondence to: Svein Vigeland Rottem. Email: svr@fni.no 
has indeed made a difference. Nevertheless, what has often been lacking in the scholarly literature is a fine-grained examination addressing what determines the influence of scientific knowledge on environmental regulations of relevance to the Arctic.

I want to examine how scientific knowledge of environmental challenges in the Arctic has been used in international regulations, and can be used today. I will describe the emergence of a specific environmental regime of relevance to the Arctic, i.e., the regulation of Persistent Organic Pollutants (POPs). The story behind the international POPs regime is, however, so complex and involves so many players that it is difficult to provide more than an overview of the various causes of success and failure here. This story has, moreover, been the subject of in-depth analyses by others. ${ }^{3}$ The focus in this article is therefore narrower. I will discuss the Stockholm Convention 's relation to other legal instruments and provide an introduction on how the Convention works. Secondly, I will examine Norway's place in this regime. The account of the emerging POPs regime (with a specific focus on the Stockholm Convention) and Norway's role in it will prepare the ground for an analysis of how and why scientific knowledge on environmental challenges in the Arctic succeeds or fails. More specifically, I explore Norway's active (and successful) nominations over the past decade of new POPs for the Stockholm Convention, nominations that require a scientific knowledge basis, and where Arctic scientific knowledge has been a prerequisite for action.

\section{Framing the research question}

POPs are chemical substances that persist in the environment and are transportable over long distances. Most POPs are created by humans in industrial processes (intentionally or as byproducts). They are bio-accumulated in the food web and pose a risk to the environment and human health. Exposure to POPs can, among other things, disrupt reproductive and immune systems. ${ }^{4}$ One consequence of their transportability is their accumulation in environments where they were never used or emitted, e.g. the Arctic. Once in the Arctic, they tend to be "trapped" there, as cold temperatures favor their persistence..$^{5}$ This is why international mechanisms are needed that are capable of addressing these environmental challenges. National measures and regulations alone are not enough.

The global community has taken a number of steps to tackle the transboundary movement of POPs and their management, including negotiating multilateral environmental agreements. This article focuses on the Stockholm Convention on Persistent Organic Pollutants, and one important property of the convention in particular, the opportunity to propose or nominate new candidates to the list of already regulated POPs. Adopted and opened for signature on 22 May 2001, the agreement called for international action on 12 POPs (the "Dirty Dozen") but recognizes that regulating the Dirty Dozen is only the initial step. After the signing of the Stockholm Convention, 14 new substances have been added to the list. ${ }^{6}$ The nomination procedure takes place in the interface between science and policy. Norway, together with 


\section{S. V. Rottem}

the EU, has been at the forefront in this work. The question guiding the second part of the article is what determined the use of scientific knowledge in the Norwegian efforts leading up to a nomination of new POPs to the Stockholm Convention. Thus, Norway is used as a case study on the use of scientific knowledge, complementing the analysis at the international level. Focus is on environmental management design, state of knowledge, degree of political and economic controversy in the issue area, and the importance of the matter in public opinion and among policy makers.

There are several reasons why such a research focus is interesting. We find numerous studies on international negotiations leading up to the Stockholm Convention, ${ }^{7}$ and Arctic knowledge transfer, ${ }^{8}$ but fewer at the national level ${ }^{9}$ and none at all on the impact of science in Norway's efforts to nominate new POPs. In international environmental politics, national initiatives and resources are key. ${ }^{10}$ No national action, no change. The processes under the Stockholm Convention are all country-driven. This is most evident in the process under scrutiny here. The scientific committee of the Stockholm Convention (POPRC) does not nominate new substances: that is the role of states. While international structures, discourses, and negotiations clearly frame national actions and negotiations, ${ }^{11}$ in this case, attention is directed at the role of domestic actors (i.e., the Norwegian environmental management system), the point being that without insight into the preconditions of state action, an important piece of the picture informing efforts to strengthen the Stockholm Convention (or any international environmental agreement), is missing.

Norway has a long history of establishing regulations to control environmental contaminants such as POPs, and the Norwegian environmental authorities have also supported global work in this field (the Stockholm Convention). Norway's more proactive engagement is more recent, however. This is evident in efforts to improve knowledge of possible new POPs and propose new candidates when available information indicates the criteria (in Annex D of the Stockholm Convention) are met. In 2005, Norway initiated the process of nominating pentabromodiphenyl ether (PentaBDE). ${ }^{12}$ The substance was added to the list in 2009. In 2008, Norway nominated hexabromocyclododecane (HBCD) ${ }^{13}$, which appeared on the list in 2013. Norway also started work on decabromodiphenyl ether (DecaBDE) ${ }^{14}$ in 2013 (still not on the list at the time of writing). Scientific findings in the Arctic region have been essential in this endeavor.

I analyze here the behavior of domestic actors, or more precisely how and why Arctic science is used by domestic actors. My main question is thus not whether Norway has influenced the work of the Stockholm Convention. The fact that Norway has succeeded in its efforts to nominate new POPs for inclusion on the list shows that Norway does indeed have influence. On the other hand, the behavior of domestic actors cannot easily be separated from that of international actors. Influence motivates action, and Norwegian environmental authorities will consider whether they can make a difference before choosing their mode of response, here by providing the given scientific knowledge needed to proceed with a nomination. My ambition is thus to look at the process of selecting a pollutant for nomination (and introducing 
it into formal negotiations at the international level). I shall only indirectly explain what it is that motivates Norway, ${ }^{15}$ and analyze instead the room for maneuver in this field of environmental management. An analysis of environmental authorities' use of science can also tell us something about how and why scientific knowledge on the Arctic can make a difference, thus improving our understanding of how Arctic science "travels" to global governance.

In the first section, I outline the analytical framework. I then provide a brief history of the regulation of POPs, the Stockholm Convention, and the nomination of new substances, emphasizing the role of Norway and Arctic science production. In this section I will also discuss the Stockholm Convention in relation to other legal instruments and provide an introduction to how the Convention works. In the last section of the paper, I discuss how Norway goes about nominating new POPs and ask how and why scientific knowledge is used in Norway's efforts to nominate new POPs to the Stockholm Convention. The analysis is based on interviews with senior officials at the Norwegian Environment Agency (MD), Ministry of Climate and Environment (KLD), and several scientists. ${ }^{16}$ The empirical data also consist of primary (budgets, statistics, white papers, etc.) and secondary sources (scientific reports and articles, and so on).

\section{Scientific use ${ }^{17}$}

Which analytical tools can we use to discuss the use of science in environmental management? A basic assumption is that the extent to which scientific knowledge is used in environmental policy depends on organization, the state of the knowledge, degree of political and economic controversies in the issue area, and public and political attention.

Management systems ${ }^{18}$ rely on research institutions. Decision-makers are exposed to complex scientific findings produced by a variety of knowledge producers in different issue areas. ${ }^{19}$ In the present case, it is important to ascertain how knowledge produced at different levels and in different sectors is integrated as part of the knowledge base of the environmental management system. It is therefore important to look at how the Stockholm Convention and the Norwegian environmental management system in relation to POPs is set up. Organizational structure can either limit or enable the integration of science in regulation. Different types of organizational structure hierarchic, specialized, and loosely structured - are known to affect the integration of science in regulation. ${ }^{20} \mathrm{~A}$ basic assumption in our case is that a mature (long history of research and regulation) and specialised management system have increased the influence of science in both the regulation of POPs and the nomination of new ones.

A second variable is state of knowledge. A well-established hypothesis is that the more conclusive and consensual the state of knowledge, the more likely it will be used as a basis in decision-making. That is, scientific advice is more easily followed when it rests on scientific consensus. Developments in the ozone and acid rain regimes illustrate the point in that the emergence of consensual scientific knowledge was 


\section{S. V. Rottem}

an important factor behind the increased effectiveness of these two environmental regimes. ${ }^{21} \mathrm{~A}$ vital question then is whether it is possible to trace such consensus to the state of knowledge on POPs in general and Norway's nominations in particular.

Furthermore, there is general agreement in the literature that the nature of the problem affects the influence of science. ${ }^{22}$ The more politically controversial the problem/issue area, the less likely it is that scientific evidence will be used to inform important decisions. Two dimensions are helpful in this regard: political cost and economic cost. Political cost refers to the divergent preferences of relevant actors, differences which in turn are likely to hamper the work of nominating a new substance. Economic cost refers to the strain a nomination (and nomination process) puts on financial resources (and commercial actors). To illustrate, science has been met with less resistance in the low-conflict ozone regime than in the far more politically contentious issue of climate change and biodiversity regimes. ${ }^{23}$ It is therefore pertinent to ask whether international and national work on POPs in general and in selecting new substances for nomination has been politically and commercially/economically controversial, and whether this has increased or lessened the use of scientific knowledge.

A fourth contextual variable is the issue's standing on the political and public agenda. For low-conflict issues, public and political attention tends to increase the influence of science, but for problems involving high levels of conflict, this attention may increase polarization and create difficulties for rational scientific input. The International Whaling Commission (IWC) is a typical case in point. Here one could argue that science has not been able to touch the (ethical) heart of the matter. Due to high levels of political conflict and public attention regarding whaling in recent decades, scientific advice, although advanced and highly consensual, has largely been disregarded. ${ }^{24}$ Does the level of public and political attention determine the use of scientific knowledge in our case?

Bringing these variables together, the proposal is that a mature and specialized environmental management system, consensual knowledge and high public and political attention in a low-conflict area have made it easier for Arctic scientific knowledge to end up in an international convention. First, it is necessary to look at international and regional cooperation mechanisms and initiatives, by briefly reviewing the history of POP regulation and the Stockholm Convention, and by discussing the Convention's position in the legal landscape on POPs. This will also show that Norway and the Norwegian scientific community have played an important role in the regulation of POPs and science production, providing us with the historical background for Norway's proactive engagement over the past decade in nominating new pollutants. It will also show the importance of Arctic science.

\section{A short history of regulations of POPs}

When and how did POPs emerge as a scientific and political concern? ${ }^{25}$ The use of certain chemicals in industry and in pesticides increased dramatically during the 
1960s and 1970s. Rachel Carson's Silent Spring, published in the United States in 1962, helped make the public aware of the dangers of DDT and other pesticides. ${ }^{26}$ According to Selin, ${ }^{27}$ the discovery of a wide range of hazardous chemicals in (Northern) areas far removed from large-scale industrial and agricultural activities dates back to the 1960s and 1970s. One important contribution was the Swedish scientist Sören Jensen's discovery of PCBs in Baltic Sea fish in the mid-1960s. By the 1970s, there was growing awareness of increasing concentrations of contaminants entering the air, soil and water. In response, the U.S. banned DDT in 1972, except for uses critical to public health, and in 1973, the OECD Council called for restrictions on the production and use of specific chemicals, including PCBs. The pattern was repeated in Norway. DDT was prohibited as a pesticide in 1970 and PCB production and new uses were prohibited altogether in $1980 .{ }^{28}$ Moreover, the discovery of surprisingly high contamination levels in the mid and late 1980s sparked new concern. In 1985, Canadian scientists Kinloch and Kuhnlein found in separate studies high concentrations of PCBs and other POPs and metals in food species of Indigenous Peoples in northern Canada and high blood concentration levels for PCBs in parts of the population..$^{29}$ Norway also has a long history of research on POPs,$^{30}$ with the Norwegian Institute for Air Research (NILU) playing an especially prominent role in providing data on how pollutants travel by air. ${ }^{31}$ Thus, POPs were on the scientific, political, and public agenda in the Nordics and in Canada, above all thanks to scientific findings from the Arctic. ${ }^{32}$

In 1989, the Working Group on Effects under the Convention on Long-range Transboundary Air Pollution (CLRTAP) was persuaded to include hazardous organic substances in its work plan, and in 1990, the Executive Body of CLRTAP decided to initiate POPs assessments. Relevant work was at the same time progressing under the Arctic Environmental Protection Strategy (AEPS). ${ }^{33}$ AEPS, established in 1991, was the forerunner of the Arctic Council. In fact, one of the main reasons for its establishment was scientific discoveries of high levels of POPs and heavy metals in the Arctic. Furthermore, cooperation between Canada and Sweden led to the establishment of a CLRTAP POPs Task Force in 1990, followed by a series of scientific assessments and political meetings, leading to more formal discussions on regional regulations. ${ }^{34}$ In CLRTAP, the final meeting of the preparatory working group was held in October 1996 and protocol negotiations started in January 1997. The final negotiation session took place in February 1998. The CLRTAP POPs Protocol was then adopted in Aarhus June 1998. Annex I contained 10 pesticides and three industrial chemicals. Norway was not a key player here, but Arctic scientific knowledge was instrumental in setting the agenda.

At the same time, acknowledging that POPs not only were a European and North American concern, UNEP began investigating POPs and produced a short list of substances. UNEP's Governing Council adopted Decision 18/32 in 1995 in which it called on the International Forum on Chemical Safety (IFCS), the Inter-Organization Programme for the Sound Management of Chemicals (IOMC), and the International 


\section{S. V. Rottem}

Programme on Chemical Safety (IPCS) to conduct an international assessment of 12 POPs and develop recommendations on international action. In November 1995, the Intergovernmental Conference to Adopt a Global Programme of Action for Protection of the Marine Environment from Land-based Activities (GPA) put POPs on their agenda, and called for negotiations on a legally binding treaty on POPs. In 1996, an IFCS ad hoc working group recommended beginning negotiations on a legally binding instrument, giving UNEP the basis to develop a mandate for global negotiations. ${ }^{35}$ At the same time, the Arctic Council was established and the Arctic Monitoring and Assessment Programme (AMAP) (an Arctic Council working group) provided further scientific input on global processes. ${ }^{36}$ In this respect, it is worth noting that Norway has been one of the most important financial and political contributors to AMAP's work on POPs, and AMAP's secretariat is located in Norway. ${ }^{37}$ Norway played an important role, albeit more as a financial contributor than a political driving force.

In extension of this, the UNEP Governing Council called on UNEP to prepare a legally binding international instrument on POPs. Negotiations for a global POPs treaty began in Montreal in July $1998^{38}$ and the Stockholm Convention was signed in 2001, with 150 signatories agreeing to take action to reduce or eliminate the production and release of the "Dirty Dozen". Norway ratified in July 2002 and the Convention entered into force May 2004. This short story on the regulation of POPs tells us that Arctic science was setting the agenda and that Norway and Norwegian researchers played an important role in this area of environmental management.

\section{The Stockholm Convention and its relation to other legal instruments}

As set out in Article 1, the objective of the Stockholm Convention is to protect human health and the environment from persistent organic pollutants. One of the main provisions is that the Convention requires each party to prohibit and/or eliminate the production and use, as well as the import and export, of the intentionally produced POPs listed in Annex A to the Convention. Annex A allows for the registration of specific exemptions for the production or use of listed POPs. The import and export of chemicals listed in Annex A can take place under specific restrictive conditions. Furthermore, the Convention restricts the production and use, as well as the import and export, of the intentionally produced POPs listed in Annex B to the Convention. Annex B allows for the registration of acceptable purposes for the production and use of the listed POPs, and for the registration of specific exemptions for the production and use of the listed POPs. The import and export of chemicals listed in Annex B can take place under specific restrictive conditions, as set out in paragraph 2 of Article 3. Moreover, there is a provision aimed at reducing or eliminating releases from the unintentionally produced POPs listed in Annex C.

The Convention promotes the use of best available techniques and best environmental practices for preventing the release of POPs into the environment and 
ensuring that stockpiles and waste consisting of, containing or contaminated with POPs are managed safely and in an environmentally sound manner. Other provisions of the Convention relate to the development of, e.g., implementation plans, information exchange, public information, awareness and education, and research.

Of particular interest here, the Convention provides for procedures for the listing of new POPs. A committee composed of experts - the Persistent Organic Pollutants Review Committee (POPRC) - examines proposals for the listing of chemicals in accordance with the procedure set out in Article 8 and the information requirements specified in Annexes D, E, and F of the Convention. These scientific review processes have increased the number of listed POPs. When a POP is proposed for listing under the Stockholm Convention, a party must first submit a proposal and provide a scientific justification for the need for global control. A scientific evaluation is thereafter carried out in the respective technical subsidiary bodies under the Convention by experts from various countries. Since the signing of the Stockholm Convention, 14 new substances have been added to the list, including certain polycyclic aromatic hydrocarbons (PAHs), brominated flame retardants, and other compounds. Thus, at the international level, the process of adding new POPs goes through four stages. In the first stage, the Expert Committee of the Stockholm Convention considers whether the substance proposed for listing fills Convention criteria and whether there is reason to believe the substance may be a POP. The background information is collected and submitted by the nominating party. In the second stage, the Expert Committee creates a global risk profile and assesses whether the substance is a POP. Health and environmental effects are considered, and it is discussed whether the substance should be banned or strictly regulated globally. In the third stage, a global assessment of remedial measures looks at socio-economic consequences of regulating the production and use of the substance, the availability of substitutes, and the costs of phasing out the nominated substance. Finally, the Assembly, the supreme decisionmaking body under the Convention, adopts a final decision on whether to have the substance listed and how it should be listed. This is a scientifically demanding and time-consuming process.

In 2005, five chemicals were proposed for review (nominated), two by the EU, one by Mexico, one by Norway (PentaBDE), and one by Sweden. In 2006, five more substances were nominated, two by Mexico and three by the EU. At its fourth meeting, in May 2009, the Conference of the Parties listed nine of these substances. ${ }^{39} \mathrm{At}$ its fifth meeting, in May 2011, the Conference of the Parties listed technical endosulfan and its related isomers with a specific exemption. Endosulfan was nominated by the EU. At its sixth meeting, from 28 April to 10 May 2013, the Conference of the Parties listed HBCD with specific exemptions. This substance was nominated by Norway in 2008. At its seventh meeting, 4-15 May 2015, three new substances were listed. As previously mentioned, Norway nominated DecaBDE in 2013.

To understand the Stockholm Convention's special position, we also need to see how it relates to other international regulations. The Convention covers a particular 


\section{S. V. Rottem}

group of substances, POPs, and therefore only coincides directly with the POPs Protocol to the LRTAP. ${ }^{40}$ The LRTAP is similar to the Stockholm Convention in having a mechanism for including new substances. The inclusion criteria and the regulations are also similar. The major differences between the two conventions lies first in the fact that the one is global and the other regional, and second in the reporting, i.e., how efficiency and performance are measured. In the POPs Protocol to LRTAP, there is currently an agreement to await the processes in Stockholm. In practice, no substances are being considered under the POPs Protocol to the LRTAP, while awaiting the process in Stockholm and, if necessary, setting forth regulations under the LRTAP. This is in order to save resources and not have parallel processes. This has been an important point for Norway, ${ }^{41}$ and it shows how the Stockholm Convention takes precedence.

Stockholm also overlaps the Basel Convention, ${ }^{42}$ but only with regard to POPs waste regulation. The division of labor between the Stockholm Convention and the Basel Convention is set out in Article 6 of the Stockholm Convention. In practice, Stockholm mandates Basel to determine limit values and what is considered suitable treatment of waste, etc., in line with Article 6 paragraph 2. The decision of the Stockholm Conference of Parties (COP) is reflected in a separate decision by the Basel $\mathrm{COP}$, and on that basis Basel then proceeds to formulate recommendations on the treatment of POPs containing waste. However, these guidelines are not legally binding in the same way as the requirements of the Stockholm Convention. Basel recently appointed its own working group on POPs waste: the Small Intersessional Working Group (SIWG) on POPs. This specialist forum was established as part of the synergies between the Stockholm, Rotterdam, and Basel conventions with a view to enhancing inter-convention collaboration while avoiding duplication/omissions and promoting more comprehensive understanding and unified communication procedures across the conventions. ${ }^{43}$

There is also some overlap between the Rotterdam and Stockholm conventions in that both cover some of the same substances, such as the brominated flame retardants penta- and octaBDE, for example, and in that substances that are banned or strictly regulated in a country as a result of global regulations by the Stockholm Convention must be notified to Rotterdam. However, as a convention, Rotterdam differs clearly from Stockholm in being merely a notification system for the export of certain hazardous chemicals. This means that, unlike Stockholm, it contains no bans/ regulations, which makes it more akin to Basel, which is also a notification system for the export of waste.

While substances are not nominated under the Rotterdam Convention, States are required nevertheless to report/notify the Convention if a national ban is introduced. All notifications are evaluated on the basis of a set of criteria specified by the Convention (Annex I and II). ${ }^{44}$ When two notifications from two regions meet the criteria, the Chemical Review Committee (CRC) compiles the information submitted by the countries in a Decision Guiding Document (DGD) and a proposal is issued 
to include the substance on the Conventions Annex III list of substances subject to export/import notification obligations. The Rotterdam Convention undertakes no scientific assessment of the hazardousness of substances at the global level, unlike the Stockholm Convention where substances are assessed and listed subject to certain criteria based on the threat posed by properties of the substance in question to health and the environment. Under Rotterdam, judgments are based solely on the hazard assessment undertaken by the countries themselves when introducing the ban. Norway has recently contributed most to the work of the Stockholm Convention, but is also a participant in the efforts of both the LRTAP and Rotterdam. Achieving global regulation of new POPs has been the most important area of work. ${ }^{45}$

To sum up this first part of the article, John Anthony Buccini, who led the negotiations under the Stockholm Convention, describes the process toward a global agreement as "long and winding." This notwithstanding, he describes a process that at the time functioned reasonably well and without major controversy, unlike the development of a climate regime. One of the reasons, as he sees it, was the consensus on the scientific basis. Rather than a question of whether one should do something, it was when and how. ${ }^{46}$ The impact of consensual science can therefore not be overestimated. Scientific consensus is a prerequisite of success. A similar point is made by members of the Norwegian delegation to the Stockholm Convention negotiations. ${ }^{47}$ Furthermore, the human health nexus is clearer. Moreover, banning POPs does not require a transformation of energy systems.

The Convention is an important agreement for Norway. Although Norway did not play a lead role in these negotiations, ${ }^{48}$ the country has taken a leading role in the nomination of new substances, where it has been active since 2005. Only the EU and Mexico can demonstrate a similar level of activity. What this short presentation tells us is that Norway was supportive of legal regulations from the beginning and started playing a proactive role after the signing of the Stockholm Convention, and that scientific knowledge has been influential in these processes. If we look at the international regulation of POPs (including the Basel and Rotterdam conventions), the Stockholm Convention occupies a special position: this is where new POPs are nominated and evaluated globally and, if approved, regulated. It is a process where the involvement of science and individual States is of paramount importance. The question begging to be answered is what has determined the use of scientific knowledge in Norwegian efforts to nominate new POPs to the Stockholm Convention?

\section{A mature and specialized management system?}

Three national bodies are essential to the work of initiating nomination procedures, thus linking science and policy. First, there is the Ministry of Climate and Environment (KLD), which formally has the last word and lays out the general political guidelines for work on hazardous substances (including POPs). These guidelines are disseminated through legislation, white papers, and annual letters of allocation. 


\section{S. V. Rottem}

The main body in our case is the Norwegian Environment Agency (MD). MD is a governmental body under the KLD. The agency is professionally independent in the sense of having a free hand to handle different cases and make decisions. The dissemination of knowledge and provision of advice on climate and environmental matters are other critical tasks. In the area of pollutants, the agency works to acquire and disseminate information, provide expert advice, and participate in international environmental activities and negotiations. The agency has been hiring highly qualified employees in recent years with professional records in their respective fields, including POPs. ${ }^{49}$ Nevertheless, the agency employs no scientists as such on its staff and therefore has to rely on formal and informal contacts with national and international scientific communities to acquire information about the latest developments, in this case POPs. The list of such establishments is long. Two of the most important are the Norwegian Institute for Air Research (NILU) and the Norwegian Polar Institute (NPI). Air pollution information has been of critical importance in Norway's nominations, and NILU is therefore often cited as one of the most important scientific institutes in this particular policy area. ${ }^{50}$ The clear associations between these efforts and the Arctic environment have also given the NPI an important role. AMAP has been crucial as well. ${ }^{51}$ Although AMAP is not a national research institute, its secretariat is based in Oslo, as mentioned above, and is largely funded by Norway. The continuous work of AMAP since the beginning of the 1990s has been of great importance regarding keeping the environmental authorities informed on new scientific findings. Furthermore, in the last decade, numerous research programs under the auspices of the Norwegian Research Council (e.g. PROFO, FORURENS, MILJØ 2015, MILJØFORSK 2015) ${ }^{52}$ have funded projects in the scientific community investigating the consequences and persistence of POPs in the environment. What these scientific actors have in common is that the lion's share of recent research has been conducted in the Arctic.

The interaction between these three players is important. The basis for initiating a nomination process is the expertise of the Climate and Environment Ministry in dealing with environmental pollutants. The Environment Agency is given an "order" to initiate a nomination by the Ministry in a letter of allocation. ${ }^{53}$ At this stage, however, the Ministry does not compile a list of possible substances. On receiving the "order," the agency seeks first to identify appropriate substances in close collaboration with the scientific community.

It has been hard to obtain information on the procedure in the case of PentaBDE in 2005, but it appears to have been rather arbitrary. ${ }^{54}$ This is not surprising since this was the first time Norway initiated a nomination. However, Norway had acquired broad competence in international environmental negotiations during the 1990s, and was considered an important player on the international scene. ${ }^{55}$ Moreover, extensive research had been conducted. With regard to HBCD, the assessment was conducted by the agency (then known as the Norwegian Pollution Control Authority). ${ }^{56} \mathrm{HBCD}$ is also a brominated flame retardant, and the agency had acquired 
more competence in selecting pollutants for nomination. The agency was maturing and becoming more specialized.

The initial work on the latest nomination (DecaBDE in 2013) was outsourced to Bergfald, a private sector environmental consultancy. ${ }^{57}$ Their mandate was to create a general list of substances for possible nomination (to see whether they passed the Annex D criteria, aka the screening criteria). They came up with shortlist of 15 . The agency evaluated the result and ended up with two pollutants. ${ }^{58}$ It was then up to the Ministry to decide which of the substances Norway wanted to nominate. My respondents identified this kind of scientific justification as the basis for each nomination (see below) ${ }^{59}$ Regarding DecaBDE, the decision to proceed with a nomination to the Stockholm Convention was, however, also partly influenced by the fact that Norway had worked on regulations at the EU-level. ${ }^{60}$ It is also important to note that because the nomination process is so expensive (in terms of personnel and resources), the agency can only nominate one substance at a time. ${ }^{61}$

With regard to relations between the scientific community and the agency, the picture is highly complex; the research community is fragmented, including public health studies, studies of contaminant levels in Arctic species, chemical and oceanographic studies etc.. There are several formal and informal channels of communication. My respondents did not paint a clear picture. In general, however, evidence of the professionalization of management in this field was something several scientists highlighted, while also noting that employees at the Environment Agency are generally well abreast of scientific progress and have acquired specialized expertise in the "use" of scientific knowledge. An interesting example is MD's direct use of AMAP expertise in the nomination process. AMAP has provided the Norwegian delegations with slides to be presented to the scientific committee under the Stockholm Convention (POPRC). What we have seen since 2005 in Norway is a prolonged joint effort and a more mature and specialized process involving scientific communities, government bodies, politicians and policy makers to nominate new substances. This has also made it easier to prolong the lifetime of this policy. Furthermore, the previous short story on the regulation of POPs also tells us that Norway for a long period has been involved in regional and global regulations of POPs, and especially AMAP, and has developed in-depth and specialized competence in this issue area. However, a well-functioning environmental management system can only explain some of the influence that scientific knowledge has had in this area.

\section{Scientific consensus?}

As mentioned above, it is easier to gain acceptance for an environmental regulation if the scientific community describing the problem and how to address it is united. Unequivocal and frequently confirmed scientific studies revealed the damage caused by chlorofluorocarbon gases to the ozone layer. ${ }^{62}$ Another example is the work on acid rain, where it was clear that precipitation tainted by sulfur and nitrogen led to 


\section{S. V. Rottem}

the acidification of water and soil. ${ }^{63}$ In both cases, scientific consensus was essential in getting the international community to adopt regulations. If we consider the twelve substances that were initially governed by the Stockholm Convention, there was generally broad scientific consensus. As one of my respondents put it, "the question wasn't whether there should be twelve; the focus was on exemptions, criteria, and financing." ${ }^{64}$ The head of the Stockholm Convention negotiations, John Anthony Buccini, also underlines this point in his detailed account of the road toward a global agreement. ${ }^{65}$ But scientific consensus is still not a statistical quantity. Some of my respondents mentioned the increase in research activity in the international chemical industry. Industry scientists publish their research in the international scientific literature and frequently question, moreover, accepted truths. ${ }^{66}$ At the national level, this effect is mostly indirect, but in the international processes that eventually lead to the listing of a new substance, the participation and scientific status of the international chemical industry has become more pronounced. ${ }^{67}$ However, the industry is not viewed univocally and broader analysis of their role would be interesting, but is outside the scope of this article. Another recurring question in the global environmental debate concerns the precautionary principle. What does it mean to say there is sufficient knowledge of the effects of something on the environment?

However, if we look at Norway's work on new substances, there was general agreement in the scientific community that the nominated substances (PentaBDE, HBCD and DecaBDE) displayed properties of POPs and posed a danger to the environment and health. ${ }^{68}$ There is also broad scientific consensus that substances such as these (brominated flame retardants) should be regulated. This is evident in work done by AMAP. In one of the most comprehensive assessments on Arctic pollution from 2002, a key recommendation is to regulate PentaBDE. Out of three substances that "may be at or approaching levels in the Arctic that could justify regional and global action" ${ }^{69}$ PentaBDE is listed first. ${ }^{70}$ The Arctic Pollution report from 2009 highlights increased levels of HBCD. ${ }^{71} \mathrm{HBCD}$ is ubiquitous in the Arctic and there is a need for global regulation. The same pattern is evident regarding DecaBDE. ${ }^{72}$ It is also worth noting that all of these substances are brominated flame retardants. They have common characteristics, and research provides strong scientific evidence supporting regulation. Furthermore, focusing on one category of POPs has provided the Norwegian environmental management system with wide-ranging and specialist expertise on a specific category of POPs. Internationally, the picture is more complex, despite the relatively high degree of consensus here too. ${ }^{73} \mathrm{~A}$ key point in our case is that the Norwegian environmental authorities would hardly nominate a new substance if they were not more or less certain that they would succeed in their efforts, or that a nomination had a justifiable basis in broad scientific consensus. ${ }^{74}$ Consensual knowledge is, thus, a prerequisite for successful nomination. The influence of scientific knowledge is therefore dependent on the state of relevant knowledge. But this is still only part of the story. We need to take another step to get a more complete picture of the use of Arctic science. 


\section{Political and economic controversy?}

The fact that the scientific community agrees that a given substance displays the properties of a POP and should be regulated does not mean that environmental agencies (KLD and MD) inevitably will take steps to nominate them. A recurring example is climate negotiation and the unwillingness of governments to commit to internationally agreed solutions. In this connection, a distinction is often drawn between political and economic costs. Will it be politically costly to start a nomination process, and will this process and eventual nomination lead to commercial and economic challenges at the national level? In what follows, the three substances Norway has nominated will be treated as one. Although there are differences between them, these differences are not decisive with regard to economic and political controversy. It is nevertheless important here to distinguish between what is perceived as controversial at the international level and what is perceived as controversial at the national level. My analysis is limited mainly to the latter level.

Regarding the national political debate, international regulation of hazardous substances with POPs properties has been uncontroversial. Debate over the storage of environmental waste has tended to be relatively lively (i.e., between local and national politicians), not surprisingly. With regard to POPs, the picture is less complex. Norway had already regulated virtually all of the original twelve substances on the Stockholm Convention list, and the same goes for those nominated by Norway. ${ }^{75}$ One of my respondents put it as follows: "In relation to the ministry and political leadership, there isn't much we need to explain." ${ }^{76}$ Nor has the expressed desire for further international regulations of pollutants been affected by the political color of changing governments. ${ }^{77}$ In allocation letters from KLD to $\mathrm{MD}$, the importance of pressing ahead to nominate new POPs is underlined. ${ }^{78}$ So, it has not been politically controversial to support steps to strengthen the Stockholm Convention. Indeed, there has been little political interference: "politicians have been really pleased to see good and important causes getting through without controversy."79

The economic dimension is, of course, closely linked to the political. But here too, the picture is relatively clear: none of the substances Norway has nominated is produced in Norway and there have been few if any protests from Norwegian commercial actors about their nomination. On the contrary: a tightening of the rules on substances has been seen as a means of leveling the playing field with competitors, and has therefore been welcomed at the national level.$^{80}$ Another point in this connection is that setting a nomination process in motion is costly. The Norwegian Environment Agency, for example, has three experts working on these processes almost constantly. ${ }^{81}$ The Agency also funds positions and projects in various research communities. So in that sense, active participation is demanding, both in terms of personnel and money. However, looking at the wider picture, the issues are neither politically nor commercially controversial.

The international scene is certainly more complex. When deciding which substance to nominate (or which scientific knowledge to use), Norway has assessed what 


\section{S.V. Rottem}

is politically possible and prudent at the international level. One example is the decision of the KLD regarding DecaBDE. The EU (with Norwegian support) had unsuccessfully attempted to pass regulations for the EU area. It was therefore logical for Norway to bring the issue to the attention of the international community. ${ }^{82}$ The Agency also explores whether other states are considering nominating substances. ${ }^{83}$ It would not make much sense if Norway initiated a nomination process for a substance on which the EU was already working, for example. The influence of scientific knowledge is, therefore, obviously affected by international and regional initiatives. Nominating a substance is scientifically demanding and costly, so parallel processes need to be avoided.

We can therefore say that in this case science has made a difference insofar as the policy is neither economically nor politically controversial. Processing a nomination, on the other hand, is resource intensive, and - presumably - dependent on direct or indirect political support if the country is to take a leading role in the nomination of new substances or bring scientific knowledge to the attention of the domestic environmental authorities and from there to the global level. More flesh needs therefore to be attached to the bone when explaining the influence of scientific knowledge.

\section{On the political and public agenda?}

An overriding characteristic of POPs is their complexity. POPs represent a subset of thousands of chemicals on the market, each of which has unique properties and usually a dedicated scientific designation most people find hard to understand. This could possibly dissuade the public from showing any interest in the matter. The nomination of new POPs serves as an illustration. In the Norwegian public sphere, the question of contaminants attracts a great deal of interest and attention. This is not true of the individual substances Norway has nominated, as a search of Norway's largest newspaper (Aftenposten) makes clear. If we search for the individual pollutants Norway has nominated (using their specific designations), the number of hits is no more than four for the past decade. A collective search for brominated flame retardants has a higher ten-year score of 30 , just three per year, with widely varying annual figures. However, if we search using the broader category "miljøgifter" (pollutants in Norwegian) the number of hits exceeds 500. We see the same tendency in official documents from the Climate and Environment Ministry; specific designations show wide annual variations but few hits. ${ }^{84}$

Discussions concerning the individual substances have attracted neither public nor political interest. The nomination of new POPs in general is, however, still inextricably linked to the notion of Norway as an environmental champion, ${ }^{85}$ and we can therefore say that pollutants generally receive a great deal of political and public attention, even though individual pollutants fall beneath the radar. One could argue that what we have then is scientifically driven environmental foreign policy. The processes are 
so demanding that they simply do not feature in the political and public debate. One could also argue that science travels more easily if unnecessary "noise" surrounding the scientific findings can be filtered out. This is linked to Underdal's argument that high salience may increase polarization and create difficulties for scientific input. ${ }^{86}$

Another important dimension in this context is the intense public interest in the Arctic in Norway. The public agenda is highly attuned to research on Arctic-related issues (including environmental contaminants). Documents published by Norwegian authorities (whatever the governments' partisan composition) over the past decade confirm this massive interest. ${ }^{87}$ The Arctic is a popular topic with the Norwegian public and among Norwegian politicians, and environmental and climate research in the region is an important part of this picture.

What does this tell us? Basically this tells us that pollutants are on the political and public agenda, and at times at the forefront of the public mind. This impression is reinforced by the amount of attention the Arctic has attracted in recent years. Conversely, the processes leading up to a nomination of individual substances do not figure in the public debate. Despite the fact that the Norwegian Environment Agency tries to make information as readily available as possible (as one of its main tasks ${ }^{88}$ ), work on new nominations has become depoliticized. We can say that while Norway's efforts to nominate new substances have cost little politically, the political rewards have been slight as well. As one of my respondents said: "It's not hard to get politicians onboard. It's a popular issue. But attracting the interest of the media, that's a different matter." ${ }^{89}$ There are echoes here of Mitchell et al. ${ }^{90}$ who link scientific influence to whether a topic is useful and exploitable.$^{91}$ It seems that policymakers consider new nominations as something to brag about. Putting it bluntly, however, the public does not really care. Norway's "victories" in terms of international regulation rarely receive media attention..$^{92}$ However, what is essential is that the nomination procedure is perceived as politically important and useful to decision-makers. To conclude, interest in pollutants is generally high among the public and politicians, especially when the Arctic is involved, but low for individually nominated substances. One could thus argue that scientific knowledge has traveled relatively easily without much public and political "interference".

The four variables discussed here, which are largely interdependent, need to be seen in context. Broad scientific consensus, for instance, is not enough if regulations are seen to be politically and economically controversial, and a well-functioning environmental management system is lacking. Again, the challenges arising from climate change are an obvious example. Furthermore, as previous studies have shown, high public interest can have a beneficial effect on future regulations. ${ }^{93}$ As described in this paper, the picture regarding POPs is more complicated. There is great interest in environmental issues in the Arctic in general, but little in the actual scientific work of nominating new POPs. The introductory proposition, "that a mature and specialized environmental management system, consensual knowledge and high public and political attention in a low-conflict area have made it easier for Arctic scientific 


\section{S. V. Rottem}

knowledge to travel through the national environmental management system and end up in an international convention" is strengthened nonetheless. This finding confirms earlier analyses of the environmental field. But it is still difficult to corroborate Underdal's hypothesis that "high salience increases the demand for information." ${ }^{94}$ Pollutants may be high on the public agenda, but specific nominations are largely depoliticized and do not attract much public attention. The demand for information, however, does not necessarily decrease. There are indications that Norway's management of the environment in this field is largely based on trust. Politicians and KLD rely on the MD do a good job and the MD trusts the integrity of researchers.

A related question in this context is why more States do not take an active role in these processes. Canada has historically been at the forefront in terms of political awareness of and research on POPs. Canada was also active in the negotiations to formulate the Stockholm Convention. ${ }^{95}$ For Canada's part, lack of resources cannot explain their wait-and-see attitude to international POPs regulation. Canada has devoted and continues to devote substantial resources to research on POPs, Arctic environmental monitoring, etc. At the same time, Canada's Arctic policy is very industry-friendly, ${ }^{96}$ which may help explain why they have not nominated substances. To illustrate Canada's approach, the country blocked the listing of chrysotile asbestos under the 2011 Rotterdam Convention negotiations, ${ }^{97}$ a substance linked to the mining industry in Quebec, and which plays an important role nationally. Another example is Canada's wish to be granted exemptions enabling the continued use of the flame retardant dekaBDE in its automotive industry and in the recycling of the same substance. ${ }^{98}$ Evidently it is more economically and politically controversial for Canada to nominate new POPs.

For developing countries and countries with economies in transition (such as former Eastern European States), resources and capacity are the main challenges. Considerable resources are needed to nominate a substance, and the process can take several years (three to four). There is also the question of scientific expertise, which few of these States have. The Arctic States are in a special position in this respect, and their extensive work under AMAP is often used as an illustration of this status, especially regarding surveillance data from polar areas. Developing countries and countries with transitional economies are often forced to focus on other environmental challenges / types of substance than those regulated by the Stockholm Convention. Acute environmental challenges and recognized environmental hazards are higher on the agenda. In terms of chemicals, developing countries tend to have better expertise on pesticides than POPs (although pesticides can also be POPs). Regarding more general challenges, many of these States struggle with frequent shifts at the political level and high turnover in the civil services (contributing to a lack of stability), and face enough challenges in simply implementing the Convention as it is today. A related example is the effectiveness evaluation presented at the Stockholm COP this year, according to which many countries are highly unlikely to achieve the goal of phasing out PCBs by $2025 .{ }^{99}$ 


\section{Summing up}

There was broad scientific consensus that the 12 original substances on the Stockholm Convention list displayed POP properties and ought to be regulated globally. Arctic studies have played an important role in creating both awareness of these contaminants and providing scientific input. There were obviously disagreements concerning exemptions, transitional arrangements, and financial contributions, but few signatories disagreed that something had to be done given the properties of these substances. ${ }^{100}$ Several of these substances had already been banned or severely restricted by many of the signatory countries, including Norway. Although Norway was not a driving force in this process, it also supported the establishment of a global convention. One of the dynamic aspects of the Stockholm Convention in relation to other legal instruments is the opportunity it gives to governments to nominate new substances for global regulation. This process is unique to the Stockholm Convention. The Basel and Rotterdam Convention are key instruments in the POP regime, but do not have the same properties. The nomination process is demanding both scientifically, technically, and financially. Since 2001, 14 new substances have entered the list. Norway has been one of the main contributors to these processes. Success in these efforts is largely due to scientific knowledge. In this article, I have attempted to identify what has determined the use of scientific knowledge in the nomination of new POPs to the Stockholm Convention by the Norwegian government. An analysis of this question is timely given that the Stockholm Convention is driven by government involvement. Analyses of international cooperation should be complemented by national analyses explaining why some states are more "environmentally friendly" than others or, more precisely, why and how scientific knowledge influences decision-making. One of the main reasons may be that Norway is a "downstream country" and dependent on global agreements to achieve a toxin-free environment. The sharper focus on the Arctic has also given the topic more urgency in political and media circles. Key Norwegian policy documents on Norway's High North show how much attention is devoted to protection of the Arctic environment. ${ }^{101}$ However, I did not primarily set out to discover Norway's motivation but rather the conditions that made it possible for Arctic science to "travel" through the domestic level to affect regulations at the global level. At a general level, there has been little controversy over tackling pollutants in the north. Regarding specific nominations of new POPs, the conditions have allowed Norway to act as a green ambassador. Norwegian environmental authorities have largely welcomed science on POPs in general and science on the three substances Norway has nominated in particular. The laborious work on specific POPs is largely depoliticized and there have been few if any political and economic costs to extending the lifetime of this policy. But this does not mean that the nomination process (national and international) is not resource-intensive for the agency concerned (MD), requiring significant financial commitment. However, at a wider economic level, since there are no national commercial firms manufacturing 


\section{S. V. Rottem}

any of the substances nominated by Norway, no negative sentiments have been expressed by the private sector about their regulation. Rather, regulation has been seen as a competitive advantage insofar as most national regulations were already stricter than the international ones.

Lastly, one may ask why Norway got involved in the Stockholm Convention and new nominations from the start. Such an analysis must, however, be anchored in an in-depth historical description of Norway's international environmental efforts. ${ }^{102}$ Whether individuals (scientists and officials) or coincidence made the nomination of new POPs seem urgent, I shall not attempt to answer. What I can say is that the conditions have generally been right, allowing Arctic scientific knowledge an "easy" passage to international negotiations.

So what does this case study tell us? It tells us that to obtain a more complete picture of how science travels into global governance we need to bring the state in. We need to know how scientific knowledge is used (or not used) at the state level. It is therefore pertinent to ask what has determined the influence of scientific knowledge on Norwegian efforts to nominate new POPs to the Stockholm Convention. As to Norway, the case study tells us that scientific knowledge has an easy path when conditions are right. It can, of course, be noted that such a conclusion is not particularly startling. However, what is more noteworthy is the degree of depoliticization of this field. Norway's involvement in the nomination of new POPs is not dependent on high public and political interest, or on whether the subject moves up and down the popularity scale. These nominations require so much continuous work that processes must be independent of outside attention, otherwise the environmental authorities would fail. This speaks to the successful design of the Norwegian environmental management system, a system based on trust and continuity.

When analyzing how Arctic knowledge "travels" we need to understand what determines the influence of scientific knowledge. The thesis that science has an impact when the environmental management system is mature and specialized, when scientists agree, when the use of scientific knowledge is neither politically nor economically controversial, and when the issue is simultaneously part of a positive discourse (the North as a toxin-free zone), is - not surprisingly - confirmed. Norway has had little to lose by initiating work on regulating new POPs and being active in the nomination of new POPs. Being green (or using scientific knowledge) in this case has been scientifically demanding, but politically easy.

\section{Acknowledgments}

I am grateful to the Research Council of Norway for supporting the project Designing knowledge-based management systems for environmental governance in Norway through research grant no. 230374 under the MILJØ2015 programme. I further wish to thank all the members of project group and the two anonymous referees for their helpful comments. 


\section{Notes}

1. Of which the most important and prominent is the Arctic Climate Impact Assessment (Arctic Council 2004).

2. E.g. Downie, Fenge 2003; Duyck 2012; Kankaanpää \& Young 2012; Stone 2015.

3. Downie, Fenge 2003; Stone 2015.

4. For an accessible introduction see Stone 2015.

5. Hung et al. 2016.

6. For an overview see, The Stockholm Convention http://chm.pops.int/TheConvention/ThePOPs/ TheNewPOPs/tabid/2511/Default.aspx.

7. Downie, Fenge, 2003; Selin 2010; Morales 2014.

8. Downie, Fenge, 2003; Stone, 2015.

9. Huntington, Sparck, 2003 and Shearer, Han, 2003 are, however, exception.

10. Chasek, Downie \& Brown, 2017, 51-61.

11. Putnam, 1988.

12. PentaBDE (also known as pentabromodiphenyl oxide) is a brominated flame retardant. Commercial PentaBDE is most commonly used as a flame retardant in flexible polyurethane foam; it was also used in printed circuit boards in Asia, and in other applications. For an in-depth description see: http://chm. pops.int/Default.aspx?tabid=2301.

13. HBCD is a brominated flame retardant. Its primary application is in extruded (XPS) and expanded (EPS) polystyrene foam used as thermal insulation in the building industry. Other uses are upholstered furniture, automobile interior textiles, car cushions, and insulation blocks in trucks, packaging material, video cassette recorder housing, and electric and electronic equipment. For an in-depth description see: http://chm.pops.int/Default.aspx?tabid=2301.

14. DecaBDE is a brominated flame retardant. The chemical is used in conjunction with antimony trioxide in polymers, mainly in high impact polystyrene (HIPS) which is used in the television industry for cabinet backs. DecaBDE is also used for polypropylene drapery and upholstery fabric by means of back coating and may also be used in some synthetic carpets. For an in-depth description see: http://chm. pops.int/Default.aspx?tabid=2301.

15. One could argue that being a downstream Arctic state is motivation enough. But that doesn't explain the work on brominated flame retardants as such. Other substances have some of the same characteristics. Furthermore, it is often claimed that Norway considers itself as an environmentally friendly actor, and that this socially constructed notion of itself as an environmental champion is a motivation factor and makes scientific knowledge travel "easier." The assumption that being active at the international level might create openings in other areas could also explain Norway's behavior. I will not, however, pursue these arguments in this article.

16. There is little secondary literature on the subject and despite the fact that one finds more general political descriptions of Norway's engagement on environmental toxins in policy documents, it is impossible to analyze the more specific problems encountered in the selection of a new substance for nominations without interviewing actors involved. Interview data are therefore essential in my analysis.

17. This part of the article is based on Andresen, Rosendal, \& Skjærseth, 2017, building upon a framework developed by Underdal, 2000. Underdal's framework is developed for studies at the international level. I will, however, claim that it is just as relevant at the national level.

18. By 'management systems,' I mean the policy decisions, measures, rules of procedure, norms and regulations that apply to specific policy areas.

19. Skjærseth, 2004; Andresen, 2014.

20. March, Olsen, 1989; Haas, 1990; Clark et al. 1998.

21. Wettestad 2002; Skjærseth, 2012.

22. Miles et al., 2002; Underdal, 2000.

23. Andresen, Rosendal, Skjærseth 2017; Rosendal \& Schei 2011.

24. Andresen, Rosendal, Skjærseth 2017.

25. For an in-depth presentation of this history see Downie \& Fenge, 2003 and Selin, 2010. My short presentation is to a large extent based on their findings.

26. Carson, 1962.

27. Selin, 2010. 


\section{S.V. Rottem}

28. Both DDT and PCB belong to the Dirty Dozen. For a list of national regulations (with exemptions) of pesticides covered by the Stockholm Convention see: Norwegian implementation plan for the Stockholm Convention on POPs 2010, http://www.pops.int/documents/implementation/nips/submissions/Norway.pdf

29. Downie, Fenge 2003, 277.

30. Berntsen, 2011.

31. Interview Ministry of Climate and Environment (KLD), 06.04.16.

32. It is important to note the international breadth of the research community. However, my respondents and the secondary literature tend to emphasize in particular the role of North American, Swedish and Norwegian researchers.

33. Selin, 2010, 115.

34. Downie, Fenge, 2003.

35. Downie, Fenge, 2003.

36. AMAP, 1998.

37. AMAP is still an important scientific actor in the field of POPs, see AMAP, 2015.

38. Subsequent meetings of the INC were held in Nairobi, Kenya, in January 1999, in Geneva, Switzerland, in September 1999, in Bonn, Germany, in March 2000, and in Johannesburg, South Africa, in December 2000 where the negotiations were successfully completed.

39. Of ten substances nominated, nine were listed. The only exception was SCCP (Selin, 2010, 158).

40. LRTAP, Protocol to the 1979 Convention on Long-range Transboundary Air Pollution on Persistent Organic Pollutants.

41. Interview KLD 19.02.16.

42. The Basel Convention.

43. Synergies among the Basel, Rotterdam and Stockholm conventions.

44. Rotterdam Convention.

45. Interview KLD 19.02.16.

46. Buccini, 2003, 253.

47. Interview KLD 06.04.16 and interview Norwegian Institute for Air Research (NILU) 12.05.16.

48. Interview KLD 06.04.16.

49. Interview Norwegian Environmental Agency (MD) 15.12.15 and NILU 12.05.16.

50. Interview MD 15.12.15.

51. Interview MD 15.12.15; interview Akvaplan-niva AS 24.05.16 and interview Norwegian Polar Institute (NPI) 28.06.16.

52. For statistics and projects see Norwegian Research Council, https://www.forskningsradet.no/prosjektbanken.

53. Ministry of Climate and Environment 2009, 2016.

54. Interview KLD 19.02.16 and MD 15.12.15.

55. Rosendal, 2007.

56. Interview MD 15.12.15.

57. Bergfald, 2011.

58. Interview MD . 15.12.15.

59 Interview AMAP 27.03.17, Interview NPI 28.06.16 and KLD 06.04.16.

60. Interview KLD 19.02.16.

61. Interview KLD 19.02.16.

62. Skjærseth, 2002.

63. Wettestad, 2012.

64. Interview, KLD 06.04.16.

65. Buccini, 2003.

66. Interview NPI 28.06.16, Interview MD 15.12.15.

67. Interview NPI 28.06.16, Interview MD 15.12.15.

68. Interview AMAP 27.03.17, Interview NPI 28.06.16, NILU 12.05.16.

69. AMAP, 2002, 3.

70. The two other substances are polychlorinated naphthalenes (PCNs), which are not in production, and endosulfan, which were later nominated by the EU.

71. AMAP, 2009.

72. AMAP, 2015.

73. Buccini, 2003. 
74. Interview MD 15.12.15.

75. HBCD is however an exception. The non-use of this substance in national production can explain the lack of regulations, Interview MD 15.12.15.

76. Interview MD 15.12.15.

77. Ministry of Foreign Affairs, 2006 and Government, 2014.

78. Ministry of Climate and Environment, 2009 and 2016.

79. Interview KLD 19.02.16.

80. Interview MD 15.12.15.

81. Interview MD 15.12.15.

82. Interview KLD 19.02.16.

83. Interview KLD 19.02.16.

84. See KLD homepage for overview https://www.regjeringen.no/no/dep/kld/id668/

85. Berntsen, 2011.

86. Underdal, 2000 .

87. Ministry of Foreign Affairs 2006, Ministry of Foreign Affairs 2011, Government 2014. For an exploration of the Norwegian Arctic discourse, see, for example, Jensen, 2016.

88. The Norwegian Environmental Agency, Strategy 2015-2020 http://www.miljodirektoratet.no/no/ Publikasjoner/2014/Desember-2014/Miljodirektoratets-strategi-for-2015-2020/

89. Interview KLD 06.04.16.

90. Mitchell et al., 2006.

91. For an in-depth theoretical discussion see Mitchell et al., 2006. They do not treat interests as given exogenously, but assume that interests are constructed through the process of knowledge production and policy formulation.

92. Ibid.

93. Underdal, 2000.

94. Underdal, 2000.

95. Buccini, 2003.

96. Canada Government.

97. The Globe and Mail, 22.06.11.

98. IPEN Press Release, 26.04.17.

99. The Stockholm Convention, Effectiveness evaluation of the Stockholm Convention on Persistent Organic Pollutants pursuant to Article 16.

100. Interview KLD 06.04.16.

101. One could for course argue that in case of oil and gas development in Northern regions we see a completely different picture. That is, however, another story not to be told here.

102. For a historical introduction to Norway's environmental policy and engagement see Berntsen, 2011.

\section{Bibliography}

AMAP (1998) Arctic Pollution Issues: A State of the Arctic Environment Report [Online). Retrieved from: http:/www.amap.no/documents/doc/arctic-pollution-issues-a-state-of-the-arctic-environmentreport/67 [Accessed: 25.03.17]

AMAP (2002) Arctic Pollution [Online] Retrieved from: http://www.amap.no/documents/doc/arcticpollution-2002/69 [Accessed: 25.03.17]

AMAP (2009) Arctic Pollution [Online] Retrieved from: http://www.amap.no/documents/doc/arcticpollution-2009/88 [Accessed 25.03.17]

AMAP (2015) AMAP Assessment 2015: Temporal Trends in Persistent Organic Pollutants in the Arctic [Online] Retrieved from: http://www.amap.no/documents/doc/AMAP-Assessment-2015-TemporalTrends-in-Persistent-Organic-Pollutants-in-the-Arctic/1521 [Accesses 25.03.17]

Andresen, S., Rosendal, K., Skjærseth, J. B. (2017) Designing Knowledge-Based, Integrated Management Systems for Environmental Governance. In: Ariel Dinar (ed), Natural resources and environmental policy in the era of global change. Singapore: World Scientific, 439-456.

Andresen, S, (2014) The role of scientific expertise in multilateral environmental agreements: influence and effectiveness. In: Abmrus, M. et al.(eds,) The Role of 'Experts' in International and European DecisionMaking Processes: Advisor, Decision-Maker or Irrelevant Actors. Cambridge University Press, 105-125. 


\section{S.V. Rottem}

Arctic Council (2004) ACIA Policy Document [Online]. Retrieved from: http://www.acia.uaf.edu/PDFs/ ACIA_Policy_Document.pdf [Accessed: 14.03.17].

The Basel Convention on the Control of Transboundary Movements of Hazardous Wastes and their Disposal [Online]. Retrived from: http://www.basel.int/Portals/4/Basel\%20Convention/docs/text/ BaselConventionText-e.pdf [Accessed: 22.08.17].

Bergfald 2011 Identifying POP candidates for the Stockholm Convention [Online]. Retrived from: http://www. miljodirektoratet.no/old/klif/publikasjoner/2871/ta2871.pdf [Accessed: 14.03.17].

Berntsen, B. (2011) Grønne linjer. Natur-og miljøvernets historie $i$ Norge. Otta: Unipub

Buccini, J. A. (2003) The Long and Winding Road to Stockholm: The View from the Chair. In: Downie, D., L., Fenge, T. Northern Lights Against POPs. Combatting Toxic Threats in the Arctic. Montreal \& Kingston: MCGill-Queen's University Press, 224-256.

Canada Government, Statement on Canada's Arctic Foreign Policy: Exercising : Sovereignty and Promoting Canada's Northern Strategy Abroad [Online]. Retrived from: http:/www.international.gc.ca/arcticarctique/assets/pdfs/canada_arctic_foreign_policy-eng.pdf [Accessed: 18.08.17].

Carson, R. (1962) Silent Spring. Boston: Houghton Mifflin.

Chasek P.S., Downie, D.L., Brown, J.W. (2017) Global Environmental Politics. Boulder Colorado: Westview Press, 51-61.

Clark, R., et al. (1998) Integrating Science and Policy in Natural Resource Management: Lessons and Opportunities From North America, USDA Forest Service, General Technical Report [Online]. Retrieved from: http://www.fs.fed.us/pnw/pubs/gtr_441.pdf [Accessed 25.03.17]

Downie, D., L., Fenge, T. (2003) Northern Lights Against POPs. Combatting Toxic Threats in the Arctic. Montreal \& Kingston: MCGill-Queen's University Press,

Duyck, S. (2012) Which Canary in the Coalmine? The Arctic in the International Climate Change Regime. In: Koivurova, T., Alfredsson, G., Hasanat, W. (eds) The Yearbook of Polar Law. [Online]. Retrieved from: https://papers.ssrn.com/sol3/papers.cfm?abstract_id=2331137 [Accessed 29.03.17]

The Globe and Mail, 22.06.11. Canada blocks inclusion of chrysotile asbestos in UN Convention. [Online] Retrived from:http://web4.uwindsor.ca/users/w/winter/Winters.nsf/831fc2c71873e46285256d6e006c 367a/b98c7c39d61ad93485257068006c4501/\$FILE/asbestos_Canada_blocks_ban.pdf [Accessed: 18.08.17].

Government (2014) Nordkloden. Verdiskaping og ressurser. Klimaendringer og kunnskap. Utviklingen nord på kloden angår oss alle. [Online] Retrieved from: https://www.regjeringen.no/contentassets/23843eabac77454283b0769876148950/nordkloden_rapport-red.pdf [Accessed: 16.03.17].

Haas, P. M. (1990) Saving the Mediterranean: The Politics of International Environmental Cooperation, Political Economy of International Change. Columbia: Columbia University Press

Hung et al. (2016) Temporal trends of Persistent Organic Pollutants (POPs) in Arctic air: 20 years of monitoring under the Arctic Monitoring and Assessment Programme (AMAP). Barking, Essex

Huntington, H. P., Sparck, M. (2003) POPs in Alaska: Engaging the USA. In: Downie, D., L., Fenge, T. Northern Lights Against POPs. Combatting Toxic Threats in the Arctic. Montreal \& Kingston: MCGill-Queen's University Press, 214-224.

IPEN Press Release, 26.04.17. Zero Waste Europa [Online] Retrived from: https://www.zerowasteeurope. eu/2017/04/ipen-press-release-at-un-meeting-canada-and-chile-stand-alone-trying-to-legitimize-ewaste-dumping-and-promote-recycling-of-toxic-chemical-into-childrens-products/ [Accessed: 18.08.17].

Jensen, L. C. (2016) International Relations in the Arctic: Norway and the Struggle for Power in the New North. London: I.B. Tauris.

Kankaanpää, P. \&Young, O.R. (2012) “The effectiveness of the Arctic Council”, Polar Research [Online], 31, 1-14. Retrieved from: http://www.polarresearch.net/index.php/polar/article/view/17176 [Accessed: 16.03.17].

LRTAP, Protocol to the 1979 Convention on Long-range Transboundary Air Pollution on Persistent Organic Pollutants [Online]. Retrieved from: http://www.unece.org/fileadmin/DAM/env/lrtap/full\%20text/1998. POPs.e.pdf [Accessed: 22.08.17].

March, J.G, Olsen, J.P. (1989) Rediscovering Institutions: The Organizational Basis of Politics. New York: Macmillan.

Miles, E. L., et al. (2002). Environmental Regime Effectiveness: Confronting Theory with Evidence. MIT Press: Cambridge, MA.

Mitchell, R. B. et al., (2006) Global Environmental Assessments: Information and Influence. MIT Press. 
Ministry of Climate and Environment (2016). Letter of allocation, The Norwegian Environmental Agency [Online]. Retrieved from: https:/www.regjeringen.no/contentassets/ab73dcc339ba4a498f8e17df76305bed/miljodirektoratet_tildelingsbrev_2016.pdf [Accessed: 29.03.17]

Ministry of Climate and Environment (2009). Letter of allocation, The Norwegian Environmental Agency [Online]. Retrieved from: https:/www.regjeringen.no/globalassets/upload/md/vedlegg/brev/ tildelingsbrev_2009/sft_etb_2009.pdf [Accessed: 29.03.17]

Ministry of Climate and Environment, Homepage, https:/www.regjeringen.no/no/dep/kld/id668/ [Accessed: 29.03.17]

Ministry of Foreign Affairs (2006) The Norwegian Government's High North Strategy [Online]. Retrieved from: https://www.regjeringen.no/globalassets/upload/UD/Vedlegg/strategien.pdf [Accessed: 09.03.17].

Ministry of Foreign Affairs (2011) The High North. Visions and Strategies[Online]. Retrieved from: https:// www.regjeringen.no/globalassets/upload/ud/vedlegg/nordomradene/ud_nordomrodene_en_web.pdf [Accessed: 09.03.17].

Norwegian Research Council, Prosjektdatabanken [Online] Retrieved from: https:/www.forskningsradet.no/ prosjektbanken [Accessed: 09.03.17].

Norwegian Environmental Agency, Strategy 2015-2020 [Online] Retrieved from: http:/www.miljodirektoratet.no/ no/Publikasjoner/2014/Desember-2014/Miljodirektoratets-strategi-for-2015-2020/ [Accessed: 09.03.17].

Morales, M. (2014) The Stockholm Convention. Durham: Duke University. Norwegian implementation plan for the Stockholm Convention on POPs 2010 [Online] Retrieved from: http://www.pops.int/documents/ implementation/nips/submissions/Norway.pdf [Accessed: 09.03.17].

Putnam, R. (1988). Diplomacy and Domestic Politics: The Logic of Two-Level Games. International Organization. 42, 427-460.

Rosendal, G. K. (2007) 'Norway in UN Environmental Policies: Ambitions and Influence. International Environmental Agreements: Politics, Law and Economics, 7 (4), 439-455.

Rosendal, G.K., Schei, P. J. (2011) Convention on Biological Diversity: From National Conservation to Global Responsibility. In: Andresen, S., Boasson, E. L., Hønneland, G. (eds), International Environmental Agreements: An Introduction. London/New York, Routledge, 135-151.

Rotterdam Convention on the Prior Informed Consent Procedure for Certain Hazardous Chemicals and Pesticides in International Trade [Online]. Retrived from: http://www.pic.int/TheConvention/Overview/ TextoftheConvention/tabid/1048/language/en-US/Default.aspx [Accessed: 22.08.17].

Selin, H. (2010) Global Governance of Hazarddous Chemicals. Challenges of Multilevel Management. MIT PressShearer, R., Han, S.-L. (2003) Canadian Research and POPs: The Northern Contaminants Program. In: Downie, D., L., Fenge, T. Northern Lights Against POPs. Combatting Toxic Threats in the Arctic. Montreal \& Kingston: MCGill-Queen's University Press, 41-60.

Skjærseth, J. B. (ed.) (2004) International Regimes and Norway's Environmental Policy - Crossfire and Coherence. Farnham: Ashgate.

Skjærseth, J. B. (2012) International Ozone Policies: Effective International Cooperation. In: Andresen, S., Boasson, E.L., Hønneland, G. (eds), International Environmental Agreements: An Introduction. London/ New York: Routledge, 38-48.

Stockholm Convention, The New POPs [Online] Retrieved from: http://chm.pops.int/TheConvention/ ThePOPs/TheNewPOPs/tabid/2511/Default.aspx [Accessed: 16.03.17].

Stockholm Convention, POPRC reports [Online] Retrieved from: http://chm.pops.int/Default.aspx?tabid=2301 [Accessed: 16.03.17].

Stockholm Convention, Effectiveness evaluation of the Stockholm Convention on Persistent Organic Pollutants pursuant to Article 16 [Online]. Retrived from: http:/www.brsmeas.org/2017COPs/MeetingDocuments/ tabid/5385/language/en-US/Default.aspx [Accessed: 18.08.17].

Stone, D. P. (2015) The Changing Arctic Environment. The Arctic Messenger. New York: Cambridge University Press Synergies among the Basel, Rotterdam and Stockholm conventions [Online]. Retrived from: http://www. brsmeas.org/Decisionmaking/Overview/SynergiesProcess/tabid/2615/language/en-US/Default.aspx [Accessed: 22.08.17].

Underdal, A. (2000) Science and politics: the anatomy of an uneasy partnership. In: Andresen, S. et al. Science and Politics in International Environmental Regimes. Manchester: Manchester University Press.

Wettestad, J. (2002) Clearing the Air - European advances in tackling acid rain and atmospheric pollution. Farnham: Ashgate 